\title{
Characteristics of Ambiente \& Água - An Interdisciplinary Journal of Applied Science (Ambi-Agua) as completing its fourth volume
}

\author{
(doi:10.4136/ambi-agua.99)
}

\author{
Getulio Teixeira Batista
}

\begin{abstract}
Professor at the Master Degree Program in Environmental Sciences of the University of Taubaté Estrada Municipal Dr. José Luiz Cembranelli, 5.000; Bairro Itaim; 12.081-010 - Taubaté, SP

E-mail: ambi-agua@agro.unitau.br
\end{abstract}

\section{ABSTRACT}

After completing the fourth volume, since the publication of its first edition in August 2006, we are proud to report a brief characterization of Ambiente \& Água - An Interdisciplinary Journal of Applied Science, ISSN: 1980-993X, doi: 10.4136/1980-993X that is now publishing its 11th edition with 14 articles evaluated and peer reviewed. Thanks to a great support received from the scientific community, especially authors and reviewers, all editions were published on schedule, in other words, at the end of April, August, and December. The missions and goals are being achieved gradually. The number of submissions is growing exponentially, allowing improvements in the quality of published articles. There is a growing interest in the journal, not only in Brazil but also within the international scientific community, due to the open access policy and to the fact that it is listed in several indices.

Keywords: Ambi-Agua; Environment; Water Resources.

\section{INTRODUCTION}

Ambiente \& Água - An Interdisciplinary Journal of Applied Science (Ambi-Agua) is published electronically in the Internet through open access policy without any charge for submission, publication, or access to the full text version of articles. It is maintained by the University of Taubaté, which is a public university and edited by the Institute of Environmental Research in Hydrographic Basins (IPABHi), a nonprofit organization.

Ambi-Agua is indexed by several relevant indices and recognized by the scientific community. It is classified, in Brazil, as B2 in the Qualis CAPES interdisciplinary area, which is the main focus area of the journal.

It has international scope in regards to its authors, editorial board, and scientific advisory board. The institutional affiliation of the authors appears on all issues and in all published editions. By verifying the origin of its authors, it becomes clear that Ambi-Agua does not publish articles that are predominantly local or regional.

More than $95 \%$ of published scientific articles are generated from original research, and for all articles published there is an author signed declaration stating that the research has not been published in another journal.

The Journal has been published on time since August 2006, hence strictly up to date, with editions published on August $31^{\text {st }}$, December $31^{\text {st }}$, and April $30^{\text {th }}$.

It has an International Standard Serial Number for publications - ISSN (obtained from the Brazilian Institute for Information on C\&T - IBICT), which the number is 1980-993X and a doi registration: 10.4136/1980-993X. Although it publishes articles from authors of diverse backgrounds (in Portuguese, English, and Spanish), the articles are mostly written by Brazilian 
BATISTA, G. T. Characteristics of Ambiente \& Água - An Interdisciplinary Journal of Applied Science (AmbiAgua) as completing its fourth volume. Ambi-Agua, Taubaté, v. 4, n. 3, p. 18-22, 2009. (doi:10.4136/ambiagua.99)

authors. Ambi-Agua may be accessed through the link: http://www.agro.unitau.br/ambi-agua and soon at http://www.ambi-agua.net.

Several other indexes contain in their own servers the articles published by Ambi-Agua, which may be accessed directly from their site:

REDALYC: http://redalyc.uaemex.mx/redalyc/src/inicio/HomRevRed.jsp?iCveEntRev=928

SOCOLAR: http://www.socolar.com/vn.aspx?id=6545

SUMÁRIOS.ORG: http://www.socolar.com/vn.aspx?id=6545

Other indexes collect Ambi-Agua metadata and send queries directly to the Journal's web page, such as:

AVANO - A Marine and Aquatic Sciences OAI Harvester: http://www.ifremer.fr/avano/ archives.htm

DOAJ: http://www.doaj.org/doaj?func=openurl\&genre=journal\&issn=1980993X

ENVIRONMENT COMPLETETM: http://www.ebscohost.com/titleLists/eih-coverage.htm

LATINDEX: http://www.latindex.unam.mx/revista.php?opcion=1

LivRe: http://livre.cnen.gov.br/ConsultaPorLetra.asp?Letra=A

Open Journal Systems: http://www.openarchives.org/Register/ListFriends http://www.agro.unitau. br/seer/index.php/index/oai

PERIODICA - Índice de Revistas Latinamericas em Ciência: http://dgb.unam.mx/periodica.html

Periódicos CAPES - O Portal Brasileiro de Informação Científica: http://acessolivre.capes.gov.br/pesquisa.do?palavra=ambiente\&letra $=\& e d i t o r=\& a s s u n t o=\&$ tipo

$=$ All \&nac $=0 \&$ gratis $=$ true

SWETS: http://www.swets.com/

The University of Illinois OAI-PMH Data Provider Registry: http://gita.grainger.uiuc.edu/registry/details.asp?id=2190

The Public Knowledge Project (University of British Columbia e Simon Fraser University): http://harvesters.sfu.ca/demo/index.php/browse/index/677

\section{Journal mission and editorial policy}

This scientific journal accepts unpublished manuscripts, with relevant scientific contribution, in the interdisciplinary thematic area that includes Environmental Sciences, Water Resources, Hydrology, Hydrogeology, Environmental and Sanitation Engineering, Forest Engineering and Forest Resources, Ecology, Aquiculture, Oceanography and Fishing Resources, Agronomy, Agrometeorology and Agricultural Engineering, Global Change, Fishing Engineering, Environmental Zootechny, Geography, and Geology. As well as, in the areas of Remote Sensing, Geoinformation, Spatial Analysis inasmuch as they are related to water or Environmental Sciences.

This journal is published every four months (April 30. August 31, and December 31) with unpublished articles that report research results related broadly with environmental sciences and water resources. The Journal's short name is Ambi-Agua. Review articles would be published exceptionally only if they provide a substantial critical analysis of recent relevant topics.

Every submitted manuscript is examined by the editor to verify whether or not the content rests within the focus of the journal and if the manuscript was prepared in agreement with the Journal instructions (Author Guidelines - http://www.agro.unitau.br/seer/index.php/ambi- 
agua/about/submissions\#authorGuidelines). The editor can reject the article if he finds: lack of adherence to the instructions; inappropriate textual description; or lack of scientific or technological merit. Once this phase is overcome, the editor may send the article to one or two members of the Editorial Board for them to suggest at least two peer reviewers to evaluate the submitted manuscript. The reviewers are all scientists that work in areas related to the theme of that manuscript, therefore, they are fully qualified to evaluate the manuscript and to recommend acceptance or rejection. Most of the time, reviewers suggest improvements in order to make the manuscript publishable. Reviewers receive the manuscripts without any author identification information, specific instructions concerning the review procedure, and an evaluation form (http://www.agro.unitau.br/seer/files/review_form.doc) to convey their comments and recommendations about the acceptance, correction, or rejection of the manuscript.

Reviewers should strictly consider all evaluation criteria included in the form and would examine the quality and correctness of the manuscript. In all stages of the review process, the reviewers are not informed about the authors' identity as well as the authors are not informed about reviewers' identity.

After examining reviewers' recommendations, the editor makes one of the following decisions: accept the article as is, accept the article with necessary changes, or reject the article. In this case of acceptance with changes, the editor sends the article back to the authors with a list of corrections to be implemented. If the corrections didn't modify the content and structure of the article significantly, the editor reads the article and concludes the process. Otherwise the editor could opt to send back the edited version of the manuscript to the same reviewers. Reviewers could also ask to review the manuscript after authors have made the suggested corrections.

Once the final version of the manuscript is approved by reviewers and received by the editor, he will notify the authors about the acceptance indicating, also, the volume and number of the issue in which the article will be published. Prior to publishing that issue, the corresponding author will receive a proof of the article to be checked and approved within 48 hours, electronically. Immediately after, authors should send by regular mail a signed authorization form, authorizing that publication and declaring that the manuscript has not been previously published in another scientific journal. Any existing mistakes such as pages without numbering, references mentioned in the text that don't appear in the reference list, and small discrepancies between the English and Portuguese abstracts are examples of small errors that might be corrected at that last stage.

In the case of rejection, the editor notifies the corresponding author the reasons for no acceptance. Generally, the reasons for rejection involve inappropriate content of the article compared to the journal's focus, serious violations in the publication structure, or manuscripts without scientific or technological merit.

Manuscripts submissions are always made through the Internet, using SEER system (derived from the PKP - http://pkp.sfu.ca/?q=ojs) and should always follow the norms for publication available in journal's site. If any difficulties with the system prevails, authors could send the manuscript by e-mail to the following address: ambi-agua@agro.unitau.br. 


\section{Ambi-Agua singular comparative advantage to other journals in its thematic area edited in Brazil}

Perhaps the biggest difference of Ambi-Agua is the frequency of communication between editor and authors as well as editor and reviewers. This is greatly facilitated by the use of SEER (Electronic System for Journal Editing) that was translated and customized by the Brazilian Institute of Information in Science and Technology (IBICT) based on software developed by the Public Knowledge Project (Open Journal Systems), University British Columbia. This system not only ensures the maintenance of a database of all communications as well as versions of manuscripts along the editing process, until their actual publication, but also provides the visibility of all metadata through the OAI-PMH protocol (Batista, 2008). This results in much less time between submission and publication than most similar journals.

Another important distinguishing feature is the continuous monitoring of access to the journal that accounts for each query to articles by using three tools: Google Analytics, CluterMaps, and Geovisite (Batista, 2009). In addition, the indexed services of Socol@r, Redalyc, and Sumários.org, among others, monitor the access to the various articles.

An important difference of Ambi-Agua is the membership of the Editorial Board and the Panel of Ad Hoc Assessors that includes renowned members of the international scientific community. Members of the Editorial Board are listed in the journal's site at (http://www.agro.unitau.br/seer/index.php/ambi-agua/about/editorialTeam). Ambi-Agua has now 317 Ad Hoc reviewers registered in the system. These reviewers are mainly research fellows of $\mathrm{CNPq}$ (holders of PQ fellowship), have doctoral degree with high scientific productivity, and cover a broad knowledge spectrum. The December issue every year includes a list of all Ad Hoc reviewers and a list of those that effectively evaluated manuscripts that year.

Another difference is that in addition to searching articles by keywords, authors, etc., each complete edition in a single document is available for librarians for download and print, making it available for library use as hardcopy (http://www.agro.unitau.br/seer/index.php/ ambi-agua/information/librarians).

A difference worth mentioning is the determination and motivation of Ambi-Agua Editorial Board. Without these ingredients the journal would not have gained visibility and acceptance as it has happened (Batista, 2009).

Table 1 shows the data of the last three years, the number of submissions per year, the number of articles accepted for publication, and the time between submission and publication.

Table 1. Journal statistics for 2007 to 2009.

\begin{tabular}{l|l|l|l}
\hline \multicolumn{1}{c|}{ Parâmetros } & $\mathbf{2 0 0 7} *$ & $\mathbf{2 0 0 8}$ & $\mathbf{2 0 0 9}$ \\
\hline Published editions & 5 & 3 & 3 \\
Published articles & 19 & 29 & 43 \\
Submission total & 75 & 82 & 122 \\
Peer evaluation & 21 & 48 & 68 \\
Accepted & $34(45 \%)$ & $33(40 \%)$ & $43(35 \%)$ \\
Evaluation time (days) & 75 & 58 & 54 \\
Time to publication (days) & 45 & 158 & 117 \\
Registered users & 327 & 461 & 762 \\
\hline \multicolumn{2}{l|}{ Ambi-Agua was effectively launched in April 2007 when the two issues of 2006 (August and } \\
December) were also published.
\end{tabular}


The goals for the next two years are to increase the number of articles published to 50 in 2010 and 60 in 2011, following to the recent increase in high quality article submissions. With the improvement of infrastructure to support the editorial process, it is expected a consistent decrease in the time between submission and publication to less than 4 months, as achieved in 2009.

With the increasing interest of the scientific community, indicated by the number of downloaded published articles and, more recently, by the number of submissions increasing to 21.6 per month, it was decided to contract the services of a third party dedicated server company with national leadership to guarantee "100\%" continuous and fast access through broadband speed. With the increasing demand of submissions we are determined to expand the infrastructure to support the editorial process by hiring more personnel for administrative assistance, layout and publishing help.

Ambi-Agua was, in its first assessment by Qualis CAPES, classified as B2 in the Interdisciplinary area. More than $10 \%$ of the papers have been submitted by authors from institutions abroad. Another goal of the journal is to join, in the short term, the ISI Web of Science, Scopus (Elsevier) and SciELO.

The Chief Editor is a member of the Brazilian Association of Scientific Editors (ABEC) and a Level 1B CNPq Research Productivity Fellow (PQ).

\section{FINAL REMARKS}

It was demonstrated that Ambiente \& Água (Ambi-Agua) is gradually reaching its goals and raising a growing interest in the scientific community. We are currently working to obtain funding from government agencies to support the Journal's editorial process that currently depends exclusively on voluntary work, with the support of the University of Taubaté (UNITAU). We are grateful to our fellow members of the Ad Hoc reviewer's panel for their competent and effective work, as well as to the authors that have submitted high quality manuscripts. It is intended, in the near future, to migrate to a server that is monitored 24 hours and 7 days a week to improve the Journal access worldwide.

\section{REFERENCES}

BATISTA, G. T. Geographical impact of scientific journals. Ambi-Agua, Taubaté, v. 2, n. 3, p. 12-18, 2007. (doi:10.4136/ambi-agua.29)

BATISTA, G. T. Progress of Ambiente \& Agua Journal after three years of life. Ambi-Agua, Taubaté, v. 4, n. 2, p. 4-9, 2009. (doi:10.4136/ambi-agua.81) 